\title{
PENGGUNAAN STRATEGI PEMBELAJARAN EKSPOSITORI BERBANTUAN METODE RESITASI UNTUK MENINGKATKAN PENGUASAAN HURUF KATAKANA SISWA KELAS XI IPB SMAN 1 SUKASADA TAHUN AJARAN 2017/2018
}

\author{
Suarningsih, N. K ${ }^{1}$, Adnyani, K. E ${ }^{2}$. K, dan Hermawan, G. $\mathrm{S}^{3}$ \\ 123 Jurusan Pendidikan Bahasa Jepang, Universitas Pendidikan Ganesha, Singaraja,Bali \\ e-mail: suarr.ningsih@gmail.com, krishna.adnyani@undiksha.ac.id, \\ satya.hermawan@undiksha.ac.id
}

\begin{abstract}
Abstrak
Penelitian ini bertujuan untuk (1) meningkatkan penguasaan huruf katakana setelah diterapkannya strategi pembelajaran ekspositori berbantuan metode resitasi pada siswa kelas XI IPB SMA Negeri 1 Sukasada tahun ajaran 2017/2018 dan (2) mendeskripsikan respons siswa terhadap penggunaan strategi pembelajaran ekspositori berbantuan metode resitasi untuk meningkatkan penguasaan huruf katakana siswa. Jenis penelitian ini adalah penelitian tindakan kelas yang dilaksanakan dalam dua siklus. Subjek pada penelitian ini adalah siswa kelas XI IPB SMA Negeri 1 Sukasada sebanyak 22 orang siswa pada semester genap tahun ajaran 2017/2018. Metode pengumpulan data yang digunakan pada penelitian ini adalah observasi, tes, kuesioner, dan wawancara. Data yang telah terkumpul dianalisis dengan teknik analisis data secara deskriptif kualitatif dan deskriptif kuantitatif. Hasil penelitian menunjukkan bahwa (1) penggunaan strategi pembelajaran ekspositori berbantuan metode resitasi mampu meningkatkan penguasaan huruf katakana siswa kelas XI IPB SMA Negeri 1 Sukasada tahun ajaran 2017/2018. Hal tersebut ditunjukkan dengan adanya peningkatan persentase ketuntasan klasikal dan rata yaitu, pada pretest rata-rata yang diperoleh 43,4 untuk ketuntasan klasikal yaitu $22,72 \%$. Pada siklus I terjadi peningkatan dengan rata-rata 73,6 dan ketuntasan klasikal yang dicapai adalah $68,1 \%$. Peningkatan yang drastis juga terjadi pada siklus II dengan rata-rata 92,3 dan ketuntasan klasikal sebesar $100 \%$. (2) Respons siswa tergolong positif, hal tersebut dilihat dari rata-rata respons siswa pada siklus I yaitu 30 , sedangkan pada siklus II respons siswa diperoleh dengan rata-rata 34,3 . Sehingga dapat disimpulkan bahwa, penggunaan strategi pembelajaran ekspositori berbantuan metode resitasi dapat meningkatkan penguasaan huruf katakana siswa dengan respons yang positif.
\end{abstract}

Kata kunci : strategi pembelajaran ekspositori, metode resitasi, huruf katakana

\section{要旨}

本研究の目的は、2017/2018 年度スカサダ第一国立高校言語クラスの二 年生において、1）直接法 と課題提出学習法の利用後のカタカナの習得力 2) 利 用された直接法と課題提出学習法に対する 学習者の反応を明らかにする。研究は、2つのサイクルで行われる授業行動研究である。調査協力 者は、2017/2018 年度スカサダ第一国立高校言語クラスの二年生、2 2 名である。調査対象は、観 察、インタビュー、アンケート、テストより収集したデータである。データを定性的記述法と記述的 な定量的により分析した。分析した結果、2017/2018 年度スカサダ 第一国立高校言語クラスの二年 生において、1）利用された直接法の課題提出学習法 により、カタカナの習得力を高められたこと は、22.72\%の修学率に対し、43.4の平均プレテストが得られたことによって示された。サイクル 1 では、平均プレテストが73.6であり、達成された修学率が $68.1 \%$ であった。また、サイクルIIで、平 均プレテストが92.3、修学率は $100 \%$ の大幅な増加が見られた。2）学習者の反応において、サイク ルIでの平均が30であり、サイクルIIでの平均が34.3であったことから、カタカナの習得力を高める のに利用された直接法の課題提出学習法に対する学習者の反応が良いということが分かった。

キーワード：直接法、課題提出学習法、カタカナ 


\section{Pendahuluan}

Bahasa asing merupakan bahasa yang dipelajari secara sengaja digunakan untuk berkomunikasi serta terdapat masukan yang dibatasi menurut tradisi dari bahasa asing itu (Oxford: 2003). Di dunia pendidikan bahasa asing dijadikan sebagai mata pelajaran yang bertujuan untuk kebutuhan pendidikan dan berkomunikasi dengan wisata asing. Bahasa asing yang diterapkan dalam jenjang pendidikan misalnya bahasa Inggris dan bahasa Jepang. Pengajaran bahasa asing pada umumnya diterapkan di SMA/SMK/MA. Pada kelas bahasa atau jurusan bahasa diberikan lebih mendalam karena bahasa asing dijadikan sebagai mata pelajaran wajib.

Mempelajari bahasa Jepang dituntut untuk menguasai 4 (empat) keterampilan berbahasa diantaranya menulis (kaku ginou), membaca (yomu ginou), berbicara (hanasu ginou), dan mendengarkan (kiku ginou). Menulis dan membaca merupakan hal yang paling dasar dari keempat keterampilan berbahasa Jepang. Manfaat menulis dalam mempelajari bahasa Jepang yaitu, membangun pemikiran kritis dan mengasah kemampuan dalam berbahasa Jepang, menyampaikan informasi dalam bentuk tulisan (kakikotoba). Sedangkan manfaat dari keterampilan membaca adalah diperoleh ilmu baru dari sumber yang dibaca. Informasi yang disampaikan secara tertulis akan lebih lama diingat dan dipahami karena penyampaian informasinya secara langsung, sehingga penerima informasi dapat langsung memahami pesan yang disampaikan. Sebagai pembelajar bahasa asing, mempelajari tulisan bahasa Jepang sangatlah penting. Pada umumnya apabila kesalahan dalam menulis huruf atau kosa kata Jepang langsung diperbaiki, maka perbaikan dari kesalahan tersebut akan lebih lama diingat.

Jepang memiliki tiga jenis huruf diantaranya, huruf hiragana, huruf katakana, dan huruf kanji. Huruf Jepang yang pertama diajarkan adalah huruf hiragana yang berjumlah 46 huruf inti. Setelah diberikan materi huruf hiragana dilanjutkan dengan pemberian materi huruf katakana dengan jumlah yang sama yaitu 46 huruf pada huruf inti. Sebagai pembelajar bahasa asing mempelajari huruf katakana sangatlah penting. Renariah (2002: 13) menyatakan huruf katakana terbentuk dari modifikasi kanji namun, goresannya terkesan kaku dan bersudut tajam sehingga huruf katakana disebut sebagai huruf laki-laki. Fungsi mempelajari huruf katakana adalah menulis nama orang asing, menulis tempat asing, dan kosa kata yang berasal dari bahasa asing. Kosa kata Jepang tidak semua dapat ditulis menggunakan huruf hiragana namun banyak terdapat kosa kata yang harus ditulis dengan huruf katakana terutama kosa kata serapan, misalnya テニス (tenisu: tenis). Bagi pembelajar bahasa asing yang mempelajari bahasa Jepang akan sering menggunakan huruf katakana terutama dalam menulis nama.

Siswa kelas X di SMA Negeri 1 Sukasada diberikan huruf hiragana sebagai awal pengenalan huruf Jepang. Setelah diberikan huruf hiragana, dilanjutkan dengan pemberian huruf katakana. Namun tidak semua sekolah memberikan huruf katakana di kelas X. Beberapa sekolah menengah atas memberikan materi huruf katakana di kelas XI. Pada umumnya siswa lebih sulit menguasai huruf katakana. Hal tersebut terjadi karena, pertama siswa kurang mampu membedakan huruf hiragana dengan huruf katakana, kedua siswa belum memahami penggunaan huruf katakana, ketiga siswa tidak mengetahui fungsi serta aturan dari huruf katakana, dan keempat siswa kurang mampu memanfaatkan waktu untuk belajar mandiri. Apabila permasalahan tersebut tidak diatasi maka siswa tidak akan mengetahui makna dari setiap goresan huruf katakana dan akan memengaruhi hasil belajar siswa.

Permasalahan tentang rendahnya penguasaan siswa terhadap huruf katakana terjadi di kelas XI IPB SMA Negeri 1 Sukasada. Dari hasil wawancara yang telah dilakukan dengan siswa kelas XI IPB memang benar penguasan huruf katakana siswa sangat rendah. Guru yang mengampu mata pelajaran bahasa Jepang di kelas XI IPB menyatakan dari 22 orang siswa, hanya 3 orang (14\%) yang mampu menguasai huruf katakana, sedangkan 19 orang $(86 \%)$ belum menguasai huruf katakana. Permasalahan lain yang terjadi adalah siswa masih bingung dengan penerapan huruf katakana, beberapa huruf katakana yang dirasakan masih mirip misalnya, シ (shi), ツ (tsu), ソ (so), dan ン (n), masih keliru dalam penggunaan 
dakuten (") dan handakuten $\left({ }^{\circ}\right)$, penggunaan vokal panjang $(-)$, serta sulit membedakan huruf hiragana dan huruf katakana.

Siswa kelas XI IPB rata-rata memiliki kemampuan yang rendah dalam penguasaan huruf katakana. Meskipun terdapat 3 orang yang menguasai huruf katakana namun 3 orang tersebut juga memiliki kesulitan yang sama dengan 19 orang siswa lainnya, seperti kurang paham terhadap penggunaan vokal panjang (-) serta keliru dalam menggoreskan huruf katakana. Karakteristik lain dari kelas XI IPB adalah pertama kurang aktif dalam mempelajari materi secara mandiri, kedua kurang membiasakan diri untuk mengisi waktu luang mempelajari kembali materi, ketiga lemah dalam mengingat pelajaran karena tidak adanya pengulangan, dan keempat ketika diberikan materi pelajaran ada beberapa siswa yang kurang fokus.

Guru pengampu mata pelajaran bahasa Jepang di kelas XI IPB SMA Negeri 1 Sukasada telah menerapkan strategi pembelajaran secara maksimal, akan tetapi strategi pembelajaran yang telah diterapkan belum bisa meningkatkan penguasaan huruf katakana siswa kelas XI IPB. Penjelasan materi cenderung dengan ceramah sehingga siswa kurang memiliki kesempatan untuk bertanya dan latihan. Selain itu, walaupun telah diberikan perkerjaan rumah, namun siswa hanya diminta untuk mempelajarinya tanpa melaporkan kembali. Hal tersebut dikarenakan strategi yang diterapkan tidak sesuai dengan karakteristik siwa kelas XI IPB. Dari permasalahan tersebut diperlukan strategi pembelajaran dan metode pembelajaran untuk meningkatkan kemampuan siswa terhadap penguasaan huruf katakana berdasarkan karakteristik siswa kelas XI IPB.

Menurut Asrori (2013) strategi pembelajaran merupakan garis besar haluan bertindak untuk mencapai tujuan yang telah ditetapkan dalam arti ilmu dan didalam memanfaatkan segala sumber yang dimiliki dan/ atau yang dapat dipakai untuk mencapai tujuan yang telah ditetapkan. Untuk merealisasikan tujuan dari sebuah strategi pembelajaran diperlukan sebuah metode yang dapat membuat peserta didik berperan aktif, memanfaatkan waktu senggang, mempertanggungjawabkan tugas yang diberikan, serta mengingat materi yang telah disampaikan lebih lama. Strategi pembelajaran dengan metode pembelajaran merupakan dua hal yang berbeda namun saling berkaitan. Menurut Sanjaya (2006: 127) "strategi menunjuk pada sebuah perencanaan untuk mencapai sesuatu, sedangkan metode adalah cara yang dapat digunakan untuk melaksanakan strategi". Dilihat dari permasalahan yang terjadi di kelas XI IPB SMA Negeri 1 Sukasada, strategi pembelajaran dan metode pembelajaran yang tepat diterapkan adalah strategi pembelajaran ekspositori berbantuan metode resitasi.

Menurut Sanjaya (2006: 179) strategi pembelajaran ekspositori adalah strategi pembelajaran yang menekankan kepada proses penyampaian materi secara verbal dari seorang guru kepada sekelompok siswa dengan maksud agar siswa dapat menguasai materi pelajaran secara optimal. Walaupun materi yang disampaikan secara verbal namun penggunaan strategi pembelajaran ekspositori tidak sama dengan metode ceramah. Menurut Aqib dan Murtadlo (2016) metode ceramah digunakan ketika materi yang disampaikan sangat padat serta peran siswa hanya mencatat penjelasan dari guru. Sedangkan, strategi pembelajaran ekspositori menurut Sanjaya (2006) yaitu adanya penekanan materi oleh pengajar kepada siswa, materi yang ditekankan merupakan materi yang belum dikuasai oleh siswa, serta siswa memiliki kesempatan untuk bertanya dan berdiskusi.

Strategi pembelajaran ekspositori dapat diterapkan apabila dalam sebuah kelas siswa memiliki tingkat kesulitan yang sama, rata-rata siswa memiliki kemampuan yang rendah, dan berpusat pada seluruh siswa. Selain itu, strategi pembelajaran ekspositori dapat diterapkan apabila situasi dan kondisi kelas tidak mendukung untuk menggunakan media. Materi yang bisa diberikan untuk penggunaan strategi pembelajaran ekspositori berupa hafalan, fakta atau data. Hal tersebut berkaitan dengan huruf katakana yang bisa dipelajari berupa fakta mengenai huruf katakana.

Dilihat dari karakteristik siswa kelas XI IPB strategi pembelajaran ekspositori memang tepat diterapkan. Siswa kelas XI IPB memiliki penguasaan huruf katakana yang rendah. Apabila dalam kelas tersebut menggunakan media kartu maka suasana kelas menjadi kurang kondusif. Dari landasan tersebut strategi pembelajaran ekspositori memang tepat digunakan 
di kelas XI IPB sesuai dengan karakteristik siswa tentunya dengan bantuan sebuah metode resitasi.

Metode Resitasi atau pemberian tugas merupakan salah satu metode mengajar yang dapat dipilih oleh pendidik, dalam pelaksanaanya pendidik menuntut agar peserta didik dapat berperan aktif dalam kegiatan belajar mengajar sehingga siswa mampu menyelesaikan tugas-tugas yang diberikan oleh pendidik untuk dikerjakan diluar jam pelajaran (Aqib dan Murtadlo, 2016: 139). Landasan yang berkaitan antara metode resitasi dengan karakterisitik siswa kelas XI IPB adalah mengaktifkan siswa untuk menemukan masalah dari tugas yang diberikan, membiasakan siswa untuk mengisi waktu luang dengan mempertanggungjawabkan tugas yang diberikan, dan memperkuat ingatan siswa terhadap materi yang diberikan dengan mengulang kembali mempelajari materi dari tugas tambahan yang diberikan. Menurut Sanjaya (2006: 183) menyatakan ekspositori akan berhasil apabila dalam proses pembelajaran siswa berada pada situasi ketidakseimbangan, sehingga mendorong siswa untuk menemukan wawasan melalui proses belajar mandiri. Proses belajar mandiri yang dimaksud adalah dengan diberikannya tugas tambahan (resitasi) siswa akan mempelajari masalah secara mandiri serta memecahkannya dengan menemukan jalan keluar sendiri. Atas dasar pemikiran tersebut strategi pembelajaran ekspositori berbantuan metode resitasi tepat digunakan di kelas XI IPB SMA Negeri 1 Sukasada tahun ajaran 2017/2018.

Penelitian dengan menggunakan strategi pembelajaran ekspositori pernah dilakukan oleh Andari (2015) dengan hasil yang diperoleh terjadi peningkatan terhadap kemampuan penguasaan tata bahasa dasar bahasa Jepang siswa kelas XI IPB 4 SMA Karya Wisata Singaraja. Selain itu, penelitian dengan menggunakan metode resitasi juga pernah dilakukan oleh Indrawan (2014) dengan hasil yang diperoleh terjadi peningkatan terhadap kemampuan menulis huruf hiragana dan katakana pada siswa kelas XI IB SMA Negeri 2 Singaraja.

Berdasarkan latar belakang permasalahan tersebut, maka rumusan masalah yang dapat disimpulan yaitu, 1) apakah penggunaan strategi pembelajaran ekspositori berbantuan metode resitasi dapat meningkatkan penguasaan huruf katakana?, 2) bagaimanakah respons siswa terhadap penggunaan strategi pembelajaran ekspositori berbantuan metode resitasi dapat meningkatkan penguasaan huruf katakana dalam pembelajaran?

\section{Metode}

Rancangan penelitian yang digunakan dalam penelitian ini adalah penelitian tindakan kelas (PTK). Alasan diadakannya penelitian tindakan kelas karena terdapat masalah di dalam sebuah kelas tentang kurangnya pemahaman siswa terhadap penggunaan huruf katakana di kelas XI IPB SMAN 1 Sukasada dengan jumlah siswa 22 orang yang terdiri dari 14 orang laki-laki dan 8 orang perempuan. Tujuan dari PTK adalah untuk mengembangkan sebuah strategi pembelajaran maupun metode pembelajaran yang efektif dan efisien dalam situasi yang alamiah.

Objek dalam penelitian ini terdapat dua jenis, yang pertama mencakup tindakan atau aktivitas siswa dalam mengikuti pembelajaran dengan penggunaan strategi pembelajaran ekspositori berbantuan metode resitasi. Sedangkan objek yang kedua yaitu mencangkup sesuatu yang mengalami perubahan atau peningkatan, dalam penelitian ini penguasaan huruf katakana sebagai variabel terikat.

Menurut Latief (2009) setiap satu siklus pada penelitian tindakan kelas dilaksanakan 2 kali pertemuan atau lebih, hal tersebut tergantung pada besaran materi pembelajaran setiap standar kompetensi, kompetensi dasar, ketersediaan waktu, serta perbaikan yang sesuai harapan. Berdasarkan teori tersebut setiap satu siklus dalam penelitian ini dilaksanakan empat kali pertemuan, tiga kali pertemuan untuk melaksanakan proses pembelajaran dan 1 kali pertemuan untuk mengadakan evaluasi.

Pada penelitian ini menggunakan empat metode pengumpulan data untuk mendapatkan data yang akurat, empat metode tersebut adalah metode observasi yang dilaksanakan setiap pertemuan pembelajaran, metode tes terdiri dari dua jenis tes yaitu pre-test dilaksanakan pada Jumat, 19 Januari 2018, post-test I dilaksanakan pada Jumat, 2 Februari 2018, dan post-test II dilaksanakan pada Jumat, 16 Februari 2018, metode kuesioner terdiri 
dari kuesioner terbuka dan tertutup yang dilaksanakan setelah pelaksanaan post-test, dan metode wawancara yang dilaksanakan setelah kuesioner. Sedangkan, instrumen penelitian yang digunakan adalah pre-test dan post-test digunakan untuk mengetahui hasil belajar siswa serta lembar kuesioner, lembar observasi, dan pedoman wawancara digunakan untuk mengetahui respons siswa.

Data yang telah diperoleh dianalisis menggunakan dua teknik yaitu, analisis secara kualitatif dari observasi, kuesioner, dan wawancara untuk mengetahui respons siswa dan analisis secara kuantitatif dari pre-test dan post-test untuk mengetahui peningkatan hasil belajar siswa.

Menurut Trianto (2010) berdasarkan ketentuan KTSP penentuan ketuntasan belajar ditentukan sendiri oleh masing-masing sekolah yang dikenal dengan istilah kriteria ketuntasan minimal (KKM), dengan berpedoman pada tiga pertimbangan, yaitu kemampuan setiap peserta didik yang berbeda-beda, fasilitas (sarana) setiap sekolah berbeda, dan daya dukung setiap sekolah berbeda. Atas dasar teori tersebut dan kurikulum yang dipergunakan di kelas XI IPB SMA Negeri 1 Sukasada yaitu KTSP maka yang dijadikan kriteria keberhasilan adalam KKM mata pelajaran bahasa Jepang di kelas XI IPB. Kriteria keberhasilan untuk menentukan penguasaan huruf katakana siswa kelas XI IPB SMAN 1 Sukasada tahun ajaran 2017/2018 dengan menerapkan strategi pembelajaran ekspositori berbantuan metode resitasi adalah apabila $75 \%$ dari jumlah siswa memeroleh nilai $75 \mathrm{ke}$ atas.

\section{Hasil dan Pembahasan Kondisi Awal}

Berdasarkan pada rancangan di metode penelitian, penelitian ini diawali dengan pemberian tes awal (pre-test). Tujuan dari pemberian pre-test adalah untuk mengetahui kemampuan awal siswa terhadap penguasaan huruf katakana. Selain itu tujuan lain dengan diadakannya pre-test yaitu untuk membuktikan bahwa kemampuan penguasan huruf katakana siswa kelas XI IPB SMA Negeri 1 Sukasada masih kurang walaupun telah diberikan di kelas X. Adapun hasil analisis pre-test yang dilaksanakan pada Jumat, 19 Januari 2018 adalah sebanyak 4 siswa (18\%) yaitu huruf リョ、ギュ、ギョ、ジャ、ジュ、 ジョ、dan ビョ, 5 siswa (23\%) dengan huruf ネ、デ、チャ、チョ、ニャ、ニョ、ヒョ、リヤ 、リュ、ギヤ、ビヤ、ビュ、ピヤ、 dan ピョ, sebanyak 6 siswa (27\%) dengan huruf ゾ、 ジ、ピ、シュ、ショ、チュ、ニュ、ヒヤ、ミョ、dan ピュ, sebanyak 7 siswa (32\%) dengan huruf ヌ、ヒ、ザ、ゼ、ダ、ズ、ド、ビ。ボ。パ、プ、シャ、ヒュ、ミヤ、dan ミュ, sebanyak 8 siswa (36\%) dengan huruf yang salah グ、ポ、danキョ, sebanyak 9 siswa (41\%) dengan huruf yang salah チ、ホ、ジ、バ、ブ、danペ, 10 siswa $(45 \%)$ dengan huruf yang salah yaitu ニ、ノ、ハ、フ、ム、メ、レ、dan キュ, sebanyak 11 siswa (50\%) huruf yang salah adalah テ、ナ、モ、ラ、ズ、danベ, sebanyak 12 siswa (55\%) dengan huruf yang salah yaituセ、タ、ル、ヨ、ゲ, danキャ, 13 siswa (59\%) dengan huruf yang salah adalahソ、ツ、へ、マ、ミ、ワ, danギ, 14 siswa (64\%) dengan huruf yang salah adalah ク 、サ、ト、ユ、リ, danゴ, sebanyak 15 siswa (68\%) dengan huruf yang salah adalah ス、ロ , danガ, serta 16 siswa (73\%) dengan huruf yang salah adalah ㄱ. Selain hasil analisis pretest, diperoleh rata-rata dan ketuntasan klasikal yang menunjukkan rendahnya penguasaan huruf katakana siswa kelas XI IPB. Rata-rata dari hasil pre-test yaitu 43,4 sedangkan untuk ketuntasan klasikal yang diperoleh yaitu $22,72 \%$. Dari 22 orang jumlah siswa kelas XI IPB hanya 5 orang $(22,72 \%)$ yang memenuhi kriteria keberhasilan minimal (KKM) mata pelajaran bahasa Jepang, sedangkan 17 orang $(77,27 \%)$ belum mencapai KKM. Dari keseluruhan nilai pre-test siswa kelas XI IPB, tidak ada siswa yang memeroleh nilai 61-70 dan 71-80. Hal tersebut menunjukkan, adanya jarak antara siswa yang memiliki penguasaan huruf katakana tinggi dan rendah. Jadi dapat disimpulkan bahwa siswa kelas XI IPB memiliki sifat yang heterogen. Keseluruhan nilai siswa ditunjukkan pada gambar 1. 
Gambar 1.

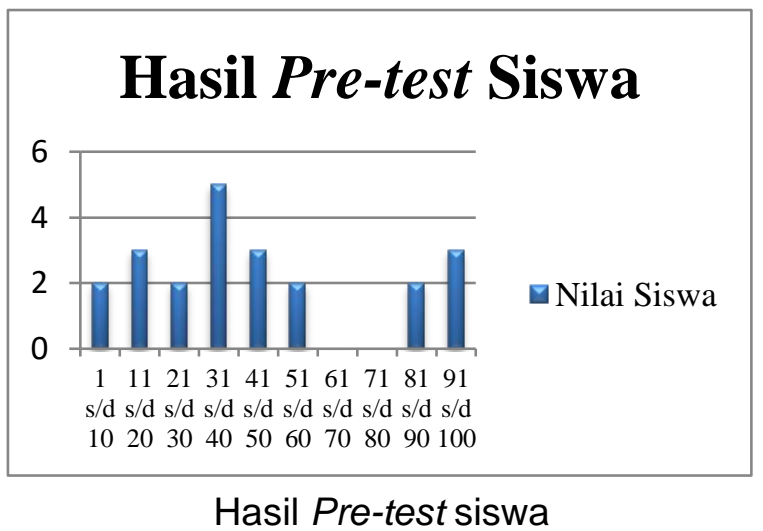

Dari hasil pre-test tersebut dapat dilanjutkan ketahap selanjutnya yaitu pelaksanaan siklus yang menggunakan strategi pembelajaran ekspositori berbantuan metode resitasi untuk meningkatkan penguasaan huruf katakana.

\section{Siklus I}

Pelaksanaan siklus I mulai diterapkan strategi pembelajaran ekspositori berbantuan metode resitasi serta ditekankannya huruf-huruf yang memeroleh nilai dibawah $75 \%$ dari hasil analisi pre-test. Pertemuan apada siklus I dilaksanakan empat kali sesuai dengan ketentuan dari bab III. Pertemuan pertama dilaksanakan pada Senin, 22 Januari 2018 dengan materi pokok yang dibahas pada pertemuan pertama yaitu, huruf katakana dari $ア$ sampai $Y$ dengan total 15 huruf. Alur kegiatan pembelajaran dibagi menjadi tiga yaitu, kegiatan awal (15 menit), kegiatan inti dengan penerapan strategi pembelajaran ekspositori dan penekanan huruf dari hasil analisis pre-test (65 menit), dan kegiatan penutup dengan penerapan metode resitasi (10 menit).

Pertemuan kedua dilaksanakan pada Jumat, 26 Januari 2018 dengan materi huruf katakana yang terdiri dari 20 huruf diantaranya dari huruf タ sampai モ. Pertemuan ketiga dilaksanakan pada Senin, 29 Januari 2018, huruf yang diberikan yaitu huruf $ヤ$ sampai ン yang berjumlah 11 huruf serta penekanan huruf dari hasil analisis pre-test yang disesuaikan dengan materi pembahasan. Pada pertemuan keempat dilaksanakan evaluasi pada Jumat, 2 Februari 2018. Adapun hasil dari pelaksanaan siklus I yaitu, (1) hasil belajar siswa yang diperoleh dari post-test I diantaranya untuk rata-rata yang diperoleh yaitu 73,6 sedangkan ketuntasan klasikal yang diperoleh adalah 68,1\%. Dari 22 jumlah orang siswa kelas XI IPB sebanyak 15 orang $(68 \%)$ yang telah memenuhi KKM, sedangkan 7 orang (32\%) belum mencapai KKM, (2) hasil respons siswa pada siklus I tergolong positif dengan rata-rata skor 30. Hasil respons siswa dari wawancara yang dilakukan adalah untuk pertanyaan pertama mengenai kesulitan yang dirasakan ketika penerapan strategi pembelajaran ekspositori berbantuan metode resitasi untuk meningkatkan penguasaan huruf katakana siswa menyatakan penjelasan yang disampaikan terlalu cepat sehingga ada beberapa goresan yang masih keliru seperti goresan huruf $ネ(n e)$, シ (shi), ツ (tsu), dan $\exists$ (yo) serta ada juga yang menyatakan siswa masih ragu-ragu untuk angkat tangan dan menjawab ketika diberikan pertanyaan karena takut salah. Pada pertanyaan yang kedua mengenai kegunaan yang didapatkan pada penggunaan strategi pembelajaran ekspositori berbantuan metode resitasi untuk meningkatkan penguasaan huruf katakana siswa menyatakan lebih mengetahui fungsi dari huruf katakana selain digunakan untuk menulis nama, huruf katakana lebih lama diingat secara otomatis karena langsung dijelaskan dan dipelajari kembali untuk tugas, lebih mudah dipahami dengan penjelasan yang disampaikan. Walaupun telah terjadi peningkatan nilai dari hasil belajar siswa, namun hasil siklus I belum memenuhi kriteria keberhasilan, maka dari itu penelitian dilanjutkan ke siklus II.

Kendala yang menyebabkan belum tercapainya keriteria keberhasilan adalah sebagai berikut, (1) siswa masih belum fokus dan masih beradaptasi dengan penggunaan strategi pembelajaran ekspositori berbantuan metode resitasi, (2) penyampaian materi terlalu cepat, 
(3) siswa kurang memiliki rasa percaya diri dan motivasi ketika diberikan kesempatan untuk latihan, (4) pengelolaan kelas yang kurang baik, (5) siswa kurang dapat membedakan huruf シdengan ツ, ヌdengan ス, ソ denganン, クdengan タ, チdenganキ, ナdenganメ, dan オ denganホ, (6) hasil analisis post-test I masih banyak huruf yang belum mencapai $75 \%$ diantaranya, huruf $ネ$ siswa yang kurang menguasai 7 orang (32\%), huruf ク siswa yang kurang menguasai 10 orang (45\%), huruf モ siswa yang kurang menguasai 11 orang (50\%), huruf チdan ヌ siswa yang kurang menguasai 12 orang (55\%), huruf シ siswa yang kurang menguasai 13 orang (59\%), huruf タ dan ホ siswa yang kurang menguasai 14 orang (64\%), huruf ツ dan マ siswa yang kurang menguasai 15 orang (68\%), dan huruf $ソ$ siswa yang kurang menguasai 16 orang $(73 \%)$.. Dari kendala tersebut perlu diadakan perbaikan pada siklus II sehingga penggunaan strategi pembelajaran ekspositori berbantuan metode resitasi dapat meningkatkan penguasaan huruf katakana siswa kelas XI IPB SMA Negeri 1 Sukasada tahun ajaran 2017/2018.

\section{Siklus II}

Siklus II dilaksanakan dengan empat kali pertemuan diantaranya, pertemuan pertama pada Senin, 5 Februari 2018. Materi yang dibahas pada pertemuan pertama siklus II mengenai huruf $カ$ sampai パ dengan jumlah yaitu 25 huruf. Selain materi tersebut, pada latihan ditekankan kembali perbedaan huruf yang menjadi kendala saat pelaksanaan siklus I yaitu,シ dengan ツ, ソ dengan ン, ク dengan タ, チdengan キ, ナ dengan メ, dan オdengan ホ. Pelaksanaan alur kegiatan pembelajaran pada pertemuan pertama siklus II dibagi menjadi tiga yaitu, kegiatan awal dengan alokasi waktu 15 menit, kegiatan inti sekaligus penerapan strategi pembelajaran ekspositori dengan alokasi waktu 65 menit, dan kegiatan penutup sekaligus penerapan metode resitasi dengan alokasi waktu 10 menit.

Pertemuan kedua dilaksanakan pada Jumat, 9 Februari 2018 dengan materi huruf yang diberikan adalah huruf $カ 3$ sampai $ハ$, selain itu pada pertemuan kali ini tidak terlepas juga dari pedoman perencanaan pembelajaran, RPP yang sudah mencangkup materi, langkahlangkah pembelajaran, strategi dan metode pembelajaran, serta sumber belajar yang disesuaikan dengan KTSP yang berlaku di kelas XI IPB. Pada pertemuan ketiga dilaksanakan pada Senin, 12 Februari 2018 yang diawali dengan mengucapkan salam pembuka yaitu “おはよう ございます” dan “Om Swastiastu”. Huruf katakana yang diberikan pada pertemuan ketiga siklus II berjumlah 18 huruf diantaranya huruf ミヤsampai ピヤ. Ke-18 huruf katakana tersebut dituliskan di papan tulis sesuai dengan goresan yang terdapat pada huruf katakana serta menggunakan spidol dengan warna yang berbeda. Pertemuan keempat untuk pelaksanakan post-test II, pembagian kuesioner, dan pelaksanaan wawancara dilaksanakan pada Jumat, 16 Februari 2018. Pertemuan I, II, dan II diakhiri dengan pengisian observasi untuk megetahui aktivitas siswa selama pembelajaran. Siklus II dilaksanakan untuk memperbaiki kendala-kendala yang terjadi pada siklus I serta pemantapan huruf dari hasil analisis post-test I. Hasil dari siklus II adalah (1) hasil belajar siswa pada siklus II yang diperoleh dari post-test II menunjukkan rata-ratanya adalah 92,3 dengan ketuntasan klasikal yaitu 100\%, hal tersebut dapat diketahui seluruh siswa memeroleh nilai diatas KKM. (2) Hasil respons siswa menunjukkan seluruh siswa kelas XI IPB merepons positif penggunaan strategi pembelajaran eskpositori berbantuan metode resitasi dengan rata-rata yang diperoleh 34,3 . Untuk hasil wawancara yang dilakukan dapat diketahu selama mengikuti proses pembelajaran tidak ada kesulitan yang dirasakan oleh siswa serta kegunaan yang diperoleh dari penggunaan strategi pembelajaran eskpositori berbantuan metode resitasi adalah menambah pengetahuan tentang huruf katakana terutama kosa kata, belajar menjadi lebih menyenangkan karena ada latihan, serta materi yang diberikan tidak mudah dilupakan karena ada tugas tambahan yang menjadikan lebih bisa memanfaatkan waktu untuk belajar. Peningkatan yang terjadi dari pre-test, Post-test I, dan Post-test Il dapat dilihat dari gambar 2.

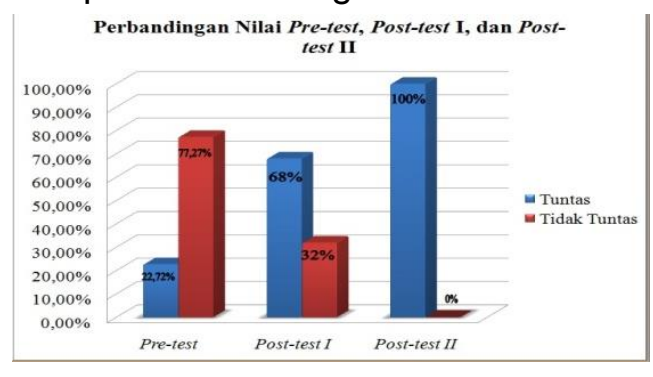




\section{Gambar 2. Perbandingan Nilai Pre-test, Post-test I, dan Post-test II}

Dari hasil tersebut dapat dinyatakan bahwa pelaksanaan siklus II telah mencapai kriteria keberhasilan yaitu $75 \%$ sehingga penelitian dapat dihentikan serta penggunaan strategi pembelajaran ekspositori berbantuan metode resitasi dapat dikatakan berhasil meningkatkan kemampuan huruf katakana siswa kelas XI IPB SMA Negeri 1 Sukasada tahun ajaran $2017 / 2018$.

\section{Pembahasan}

Berdasarkan pada temuan penelitian yang dilakukan di kelas XI IPB SMA Negeri 1 Sukasada pada mata pelajaran bahasa Jepang dengan menggunakan strategi pembelajaran ekspositori berbantuan metode resitasi mengalami peningkatan terhadap penguasaan huruf katakana siswa. Salah satu faktor yang memengaruhi terjadinya peningkatan hasil belajar siswa dalam suatu proses pembelajaran dikarenakan materi yang diberikan mampu disampaikan dengan baik serta serta didukung dengan suatu strategi pembelajaran dan metode pembelajaran disesuaikan dengan karakteristik atau kebutuhan siswa agar tercapainya tujuan pembelajaran. Penggunaan strategi pembelajaran ekspositori akan membantu siswa untuk memahami materi khususnya huruf katakana dengan baik. Selain itu, siswa yang kurang percaya diri dan kurang fokus mengikuti pembelajaran akan diberikan motivasi serta arahan agar mengikuti pembelajaran. Hal ini didukung oleh pernyataan dari Hidayah (2015) yang menyatakan tentang salah satu tujuan yang hendak dicapai dari penerapan strategi pembelajaran ekspositori adalah memfokuskan siswa dengan cara mengarahkan perhatian siswa. Ketika siswa telah mampu untuk fokus terhadap materi yang disampaikan maka suasana kelas akan kondusif serta siswa akan cepat memahami materi yang disampaikan.

Berbantuan metode resitasi akan mampu meningkatkan rasa ingin tahu siswa terhadap materi, memotivasi siswa untuk percaya diri ketika diberikan latihan soal atau ulangan, mengaktifkan siswa untuk menemukan masalah dari tugas yang diberikan, memberikan tanggung jawab kepada siswa, serta memperkuat ingatan siswa terhadap materi yang diberikan. Hal tersebut didukung oleh teori dari Wibowo (2014) yang menyatakan metode resitasi menugaskan siswa untuk mengisi waktu luang dengan hal-hal yang kondusif, memupuk rasa tanggung jawab, membiasakan siswa untuk giat belajar, dan membantu mengingat materi lebih lama. Pelaksanaan penelitian yang dilakukan dilihat dari hasil belajar siswa telah memenuhi kriteria keberhasilan. Pada siklus I diperoleh ketuntasan klasikal sebesar $68,1 \%$, sedangkan pada siklus II mengalami peningkatan yang dengan ketuntasan klasikal 100\%. Hal tersebut didukung oleh teori dari Komaidi, dkk (2011: 90) yang menyatakan sebagai kriteria keberhasilan yang dijadikan dasar dalam penelitian adalah kriteria ketuntasan minimal (KKM) yang ditetapkan oleh guru. Berlandaskan teori tersebut maka penelitian ini dapat dihentikan karena telah berhasil melampaui kriteria keberhasilan.

Pada umumnya strategi pembelajaran ekspositori dapat digunakan pada siswa yang memiliki kemampuan homogen, namun dari penelitian ini diketahui bahwa siswa kelas XI IPB SMA Negeri 1 Sukasada memiliki kemampuan yang heterogen. Hal tersebut terlihat dari hasil pre-test yang menunjukkan bahwa adanya jarak antara siswa yang memiliki kemampuan rendah dengan siswa yang memiliki kemampuan tinggi terhadap penguasaan huruf katakana. Meskipun tidak ada modifikasi dari penggunaan strategi pembelajaran ekspositori berbantuan metode resitasi yang diterapkan, tetapi hal tersebut tidak memengaruhi hasil belajar siswa. Dari hasil belajar siswa pada post-test I dan post-test II mengalami peningkatan. Untuk mengetahui respons siswa terhadap penggunaan strategi pembelajaran ekspositori berbantuan metode resitasi dilihat dari hasil kuesioner dan wawancara yang telah dilakukan. Rata-rata yang diperoleh pada kuesioner siklus I adalah 
30, sedangkan rata-rata kuesioner siklus II yang diperoleh adalah 34,3. Dari hasil kuesioner tersebut dapat digolongkan siswa merespons penggunaan strategi pembelajaran ekspositori berbantuan metode resitasi dengan positif. Sedangkan untuk hasil wawancara yang dilakukan adalah pada siklus I terdapat sedikit kesulitan yang dialami oleh siswa, namun hal tersebut dapat diatasi pada siklus II sehingga pada siklus II tidak terdapat kesulitan yang terjadi selama pelaksanaan pembelajaran. Sedangkan kegunaan yang didapatkan siswa dari siklus I sampai siklus II direspons dengan positif seperti, meningkatkan penguasaan huruf katakana, lebih mengenal fungsi huruf katakana, ingatan terhadap materi yang disampaikan lebih lama, dan mudah dipahami dari penjelasan yang disampaikan. Jadi dapat disimpulkan bahwa penggunaan strategi pembelajaran ekspositori berbantuan metode resitasi mampu meningkatkan penguasaan huruf katakana siswa kelas XI IPB SMA Negeri 1 Sukasada tahun ajaran 2017/2018.

\section{Simpulan dan Saran}

Simpulan yang dapat ditarik berdasarkan analisis terhadap data hasil PTK pada siswa kelas XI IPB SMAN 1 Sukasada dengan penggunaan strategi pembelajaran ekspositori berbantuan metode resitasi yaitu, (1) Penggunaan strategi pembelajaran ekspositori berbantuan metode resitasi dapat meningkatkan penguasaan huruf katakana siswa kelas XI IPB SMA Negeri 1 Sukasada. Peningkatan tersebut terbukti pada hasil belajar siswa yang dilihat dari pretest, post-test I, dan post-test II. Rata-rata nilai siswa yang diperoleh pada pretest yaitu 43,4 dengan ketuntasan klasikal $22,72 \%$, sedangkan pada posttest I terjadi peningkat dengan perolehan rata-rata 73,6 dan ketuntasan klasikal yang diperoleh yaitu $68,1 \%$, selanjutnya peningkatan kembali terjadi pada siklus II dengan perolehan rata-rata sebesar 92,3 dan ketuntasan klasikal yang diperoleh sebesar $100 \%$. Selain itu, bukti lain yang menunjukkan terjadinya peningkatan adalah dari bentuk perubahan siswa yang terjadi ketika proses belajar mengajar berlangsung. (2) Respons siswa kelas XI IPB SMA Negeri 1 Sukasada terhadap penggunaan strategi pembelajaran ekspositori berbantuan metode resitasi untuk meningkatkan penguasaan huruf katakana tergolong positif. Dari hasil kuesioner tertutup yang dilakukan pada siklus I diperoleh rata-rata skor yaitu 30, sedangkan hasil kuesioner tertutup yang dilakukan pada siklus II diperoleh rata-rata skor sebesar 34,3. Tidak hanya kuesioner tertutup yang membuktikan bahwa respons siswa positif dengan penggunaan strategi pembelajaran ekspositori berbantuan metode resitasi terhadap penguasaan huruf katakana siswa, namun pada hasil kuesioner terbuka juga menunjukkan respons yang positif. Pada kuesioner terbuka terdapat 3 pertanyaan, hasil respons siswa pada pertanyaan pertama siklus I sebanyak $27 \%$ sedangkan pada siklus II sebanyak $36 \%$ dengan respons mempermudah dalam mempelajari dan menguasai huruf katakana. Pada pertanyaan kedua disiklus I respons siswa sebesar $10 \%$, sedangkan pada siklus II sebesar $14 \%$ dengan respons bisa menulis nama sendiri dan menambah kosa kata. Sedangkan hasil respons siswa pada pertanyaan ketiga siklus I yaitu $14 \%$ dan untuk siklus II yaitu $23 \%$ dengan respons kelebihannya huruf katakana lebih mudah dikuasai dan dipelajari. Selain hal tersebut, dengan diterapkannya strategi pembelajaran ekspositori berbantuan metode resitasi membuat siswa lebih percaya diri untuk menjawab soal maupun latihan, ingatan siswa terhadap materi lebih lama, dan siswa menjadi aktif saat mengikuti proses pembelajaran.

Saran yang dapat disampaikan dari penelitian terdapat tiga saran diantaranya, (1) bagi guru adalah diharapkan dapat memberikan motivasi kepada guru untuk menerapkan strategi pembelajaran dan metode pembelajaran yang dapat mengetahui sejauh mana siswa menguasai bahan pelajaran serta memberikan kesempatan kepada siswa untuk berlatih dan meningkatkan rasa tanggung jawab terhadap tugas yang diberikan, (2) bagi peneliti lain diharapkan penelitian ini dapat digunakan sebagai acuan kepada peneliti lain apabila hendak melakukan penelitian pada bidang kosa kata bahasa Jepang atau mata pelajaran lainnya, namun dengan memerhatikan hambatan-hambatan yang terjadi pada penelitian ini agar penelitian yang dilakukan dapat diperbaiki dan lebih disempurnakan, serta hasil penelitian ini dapat digunakan untuk menambah ilmu pengetahuan. 


\section{DAFTAR PUSTAKA}

Andari, N. P. D. 2015. Penerapan Strategi Pembelajaran Ekspositori Berbantuan Metode Resitasi untuk Meningkatkan Penguasaan Tata Bahasa Dasar Bahasa Jepang Siswa Kelas XI IPB 4 SMA Karya Wisata Singaraja Tahun Ajaran 2014/2015. Skripsi (tidak diterbitkan). Jurusan Pendidikan Bahasa Jepang, Undiksha Singaraja.

Aqib, Zainal dan Ali Murtadlo. 2016. Kumpulan Metode Pembelajaran Kreatif dan Inovatif. Cetakan Pertama. Bandung: PT Sarana Tutorial Nurani Sejahtera.

Asrori, M. 2013. "Pengertian, Tujuan dan Ruang Lingkup Strategi Pembelajaran". Madrasah, Volume 5, Nomor2, Edisi Januari-Juni 2013 (hlm. 163-188).

Hidayah, Nurul. 2015. Penerapan Strategi Mengajar Ekspoistori (Expository Teaching) dalam Pembelajaran Aqidah Akhlak di Matholi'ul Huda 02 Srikandang Bangsri Jepara Tahun Pelajaran 2014/2015. Skripsi (tidak diterbitkan). Program Studi Pendidikan Agama Islam, Unisnu Jepara.

Indrawan, I. P. 2014. Penggunaan Metode Pemberian Tugas (Resitasi) Untuk Meningkatkan Kemampuan Menulis Huruf Hiragana Dan Katakana Siswa Kelas Xi Ib Sma Negeri 2 Singaraja Tahun Ajaran 2013/2014. Skripsi (tidak diterbitkan) Jurusan Pendidikan Bahasa Jepang, Universitas Pendidikan Ganseha Singaraja.

Komaidi, dkk. 2011. Panduan Lengkap PTK (Penelitian Tindakan Kelas) Teori, Praktek dan Contoh PTK. Cetakan Pertama. Yogyakarta: Sadba Media.

Latief, M. A. 2009. "Penelitian Tindakan Kelas". Tersedia pada http://karyailmiah.um.ac.id/index.php/karya-dosen-fs/article/view/2215 (diakses pada 11 Maret 2018).

Oxford, R. L. 2003. "Language Learning Style and Strategies: An Overview". Learning Styles \& Strategies, (hlm. 1-25).

Renariah. 2002. "Bahasa Jepang dan Karakteristiknya". Sastra Jepang Fakultas Sastra Universitas Kristen Maranatha, Volume 1, Edisi Februari 2002 (hal. 1-16).

Sanjaya, W. 2006. Strategi Pembelajaran Berorientasi Standar Proses Pendidikan. Bandung: Kencana.

Trianto. 2010. "Mendesain model pembelajaran inovatif-progresif konsep, landasan, dan implementasinya pada kurikulum tingkat satuan pendidikan (KTSP)". Jakarta: Kencana Prenada Media Group.

Wibowo, D.A. 2014. "Penerapan Metode Resitasi dan Diskusi untuk Meningkatkan Prestasi Belajar Mahasiswa Program Studi IImu Keperawatan Universitas Galuh". Pendidikan dan Kebudayaan, Volume 20, Nomor 3 (hlm. 328-339). 